\section{THE CURATIVE EFFECT OF TRADITIONAL CHINESE MEDICINE COMPOUNDED MEDICATIONS IN RELIEVING RACEWALKING FATIGUE}

\author{
OEFEITO CURATIVO DOS MEDICAMENTOS MANIPULADOS DA MEDICINA CHINESA TRADICIONAL PARA \\ ALIVIAR A FADIGADA MARCHA ATLÉTICA
}

OBSERVACIÓN DEL EFECTO CURATIVO DEL COMPUESTO DE MEDICINA TRADICIONAL CHINA PARA ALIVIAR LAFATIGADE LACARRERA

$\mathrm{TaO} \mathrm{Ma}^{1}$ (ID)

(Public Health Education)

1. College of Physical Education, Qilu Normal University, Jinan, Shandong, 250200, China.

\section{Correspondence:}

Jinan, Shandong, 250200, China. qfkfd3239xhi9@126.com

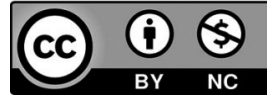

\begin{abstract}
Racewalking fatigue is a kind of fatigue symptom after a period of racewalking, which may lead to limb weakness, mental fatigue, muscle fatigue and other phenomena. If we do not timely adjust the stretching and effective treatment after exercise, it is very easy to produce sports injury and seriously affect the athletes' physical function. In order to effectively alleviate the fatigue of racewalking, this study focused on the traditional Chinese medicine (TCM) compounded medication, analyzed the mechanism of action and medicinal effectiveness of the TCM compound, and carried out control experiment on 80 male ICR mice. The mice in the experimental group were given sedentary training and racewalking training in groups. The results showed that the two groups of ICR mice, after racewalking training, had exercise fatigue symptoms and a large amount of serum lactic acid and other substances, while mice in group D treated by gavage of traditional Chinese medicine compounded medication had the symptoms of exercise fatigue, but the contents of blood urea nitrogen and lactic acid were decreased, the gastrocnemius muscle fibers were evenly arranged, the transverse lines were neat, and a rebound of protein expression. This shows that Chinese medicine compound can play a significant role in relieving racewalking fatigue.
\end{abstract}

Keywords: Medicine, Chinese Traditional; Fatigue; Walking.

\section{RESUMO}

A fadiga causada pela marcha atlética é um tipo de sintoma que acomete os atletas após um período de prática do exercício, que pode ocasionar fraqueza dos membros, fadiga mental, fadiga muscular e outros fenômenos. Na ausência de alongamento e tratamento eficaz após o exercício, as lesões causadas pelo esporte podem afetar seriamente a função física dos atletas. A fim de aliviar de maneira eficaz a fadiga causada pela marcha atlética, o presente estudo se concentrou nos medicamentos manipulados na medicina tradicional chinesa (MTC), analisou o mecanismo de ação e eficácia medicinal dos medicamentos da MTC, e realizou experimentos de controle em 80 camundongos do tipo ICR masculinos. Os camundongos do grupo experimental receberam treinamento sedentário e treinamento de corrida em grupo. Os resultados mostraram que os dois grupos de camundongos ICR, após treino de marcha atlética, apresentavam sintomas de fadiga, e grande quantidade de ácido láctico sérico, além de outras substâncias, enquanto os camundongos do grupo D tratados com gavagem do medicamento manipulado tiveram sintomas de fadiga, mas com redução do teor sanguíneo de ureia e ácido láctico, fibras musculares gastrocnêmias uniformemente arranjadas, linhas transversais regulares, e efeito rebote da expressão proteica. Isto mostra que os medicamentos manipulados da medicina chinesa podem desempenhar um papel significativo no alívio da fadiga causada pela marcha atlética.

Descritores: Medicina Tradicional Chinesa; Fadiga; Caminhada.

\section{RESUMEN}

La fatiga causada por la marcha atlética es un tipo de síntoma que afecta los atletas después de un período de práctica del ejercicio, que puede ocasionar debilidad de los miembros, fatiga mental, fatiga muscular y otros fenómenos. En ausencia de elongación y tratamiento eficaz después del ejercicio, las lesiones causadas por el deporte pueden afectar seriamente la función física de los atletas. A fin de aliviar de manera eficaz la fatiga causada por la marcha atlética, el presente estudio se concentró en los medicamentos manipulados en la medicina tradicional china (MTC), analizó el mecanismo de acción y eficacia medicinal de los medicamentos da MTC, y realizó experimentos de control en 80 ratones del tipo ICR masculinos. Los ratones del grupo experimental recibieron entrenamiento sedentario y entrenamiento de carrera en grupo. Los resultados mostraron que los dos grupos de ratones ICR, después de entrenamiento de marcha atlética, presentaban síntomas de fatiga, y gran cantidad de ácido láctico sérico, además de otras sustancias, mientras que los ratones del grupo D tratados con gavaje del medicamento manipulado tuvieron síntomas de fatiga, pero con reducción del tenor sanguíneo de urea y ácido láctico, fibras musculares del gastrocnemio 
uniformemente arregladas, líneas transversales regulares, y efecto rebote de la expresión proteica. Esto muestra que los medicamentos manipulados de la medicina china pueden desempeñar un papel significativo en el alivio de la fatiga causada por la marcha atlética.

Descriptores: Medicina Tradicional China; Fatiga; Caminata.

\section{INTRODUCTION}

Race walking is a kind of periodic endurance race, which has strong technical requirements, and has higher requirements for athletes' physical function and competitive ability. If the athletes have long-term high-intensity race walking training, but their own race walking technology is lack of standardization, and the stretching treatment after exercise is not carried out in time, the athletes will experience obvious race walking fatigue and even sports injury. ${ }^{1}$ At present, the research on the formulation and preparation of traditional Chinese medicine compound is more and more in-depth, and the role of traditional Chinese medicine compound in alleviating sports fatigue is gradually prominent. ${ }^{2}$ Traditional Chinese medicine compound can effectively improve the antioxidant capacity of the body, effectively remove the free radicals produced in the process of competitive sports, reduce the accumulation of various metabolites in the body, improve the expression ability of body proteins, and significantly improve the situation of gastrocnemius muscle nuclear migration and skeletal muscle cell ultrastructure damage. ${ }^{3}$ Based on the principle of tonifying, the traditional Chinese medicine compound integrates the curative effects of various single Chinese medicines, so as to promote the differentiation of blood cells and lymphocytes in the body, and finally achieve the significant improvement of antioxidant capacity of the body. ${ }^{4}$ After finishing the high intensity and high load race walking training, if the athletes take the Chinese medicine compound prescription appropriately, they can realize the supplement of their own body, improve the physiological function of the organs and tissues, and finally achieve the purpose of effectively relieving the race walking fatigue.

The core content of this study is to use traditional Chinese medicine compound to alleviate race walking fatigue and explore its effect. In this study, animal control experiment was used to divide male ICR mice into groups, and to compare sit training with race walking training, and whether to accept the treatment of traditional Chinese medicine compound by gavage. Animal control experiment is a necessary step in the application of drugs to human body, which can effectively avoid the unknown effects of drugs on human body. Through strict animal control experiments, the contents of drug efficacy, adverse reactions and action pathways can be clearly presented. The results of animal control experiments can be transformed into specific quantitative indicators, which will lay a solid theoretical and experimental foundation for the application of traditional Chinese medicine compound preparations in human body.

\section{RELATED WORK}

As the quintessence of our country, Chinese herbal compound plays an important role in the world medical field, and plays an important role in promoting the development of medicine. $\mathrm{Wu} \mathrm{QH}$ and his research team conducted a detailed study on the therapeutic effect of traditional Chinese medicine compound in diabetes mellitus. By analyzing the anti hyperglycemia effect and multi-component synergistic effect of Chinese herbal compound, it successfully provided a powerful reference for the clinical application of treating diabetes. ${ }^{5}$ Yang CM focused on exploring the research path and research rules of traditional Chinese medicine compound new drugs. By elaborating and discussing the evaluation knowledge of each stage of traditional Chinese medicine compound new drug pharmacy, Yang C M successfully improved the technical evaluation standard system in line with the characteristics of traditional Chinese medicine, and played a significant role in accelerating the research and development and marketing of new Chinese medicine. Wang $T$ and other scholars focused on the research of traditional Chinese medicine compound prescription, and integrated and corrected the effectiveness of traditional Chinese medicine compound in antiarrhythmic target network by constructing machine learning and molecular pathway model. Liu Yang and other researchers analyzed the quality control methods of rupishu tablets, and determined the content of salvianolic acid B in Salvia miltiorrhiza in traditional Chinese medicine prescription by HPLC. The results showed that when the content of salvianolic acid B was within a certain injection range, the average recovery rate was very high, which could assist in the effective quality control of rupishu tablets. Song y and other scholars analyzed the role of ultra-fine traditional Chinese medicine compound in the regulation of meat fat metabolism of laying hens by superfine treatment, and found that it can effectively reduce cholesterol and other effects. Liu y and his research team found that with the continuous acceleration of toxicological research process of traditional Chinese medicine, the toxic mechanism of Tripterygium wilfordii liver gradually became clear. In the study, through the elaboration of the mechanism of action of Salix toxin and the summary of the compatibility of traditional Chinese medicine preparations, we successfully excavated the method of rational application of willow in clinical application, and effectively reduced its adverse reactions to the liver.

Through the analysis of the research results of many scholars at home and abroad, it can be found that the application range of traditional Chinese medicine compound is wide, and the curative effect is significant. However, there is still a large gap in the application of traditional Chinese medicine compound prescription in the study of relieving race walking fatigue. In view of this, this study will make an in-depth analysis of the mechanism of action of traditional Chinese medicine compound, aiming to provide more scientific guidance and suggestions for Chinese medicine compound prescription in relieving race walking fatigue.

\section{EFFECT ANALYSIS OF TRADITIONAL CHINESE MEDICINE COMPOUND PRESCRIPTION IN RELIEVING RACE WALKING FATIGUE}

Bun, LDH, LD, CK, PI in serum, LG in liver and $\mathrm{Mg}$ in skeletal muscle of ICR mice are important data indexes related to exercise fatigue in ICR mice. After completing the sit in test and race walking test of all ICR mice in the four groups, the effect of Chinese herbal compound on relieving exercise fatigue in mice was observed. The effect of Chinese herbal compound on the biochemical indexes related to fatigue in mice was shown in Figure 1.

Figure 1 (a) shows the serum BUN content of ICR mice. Compared with group $A$, the serum BUN content of group B was significantly increased, and $P<0.01$, with statistical significance; compared with group $D$, the bun content of group $C$ was decreased, $P<0.05$. Fig. 4 (b) shows the detection results of $L D$ in serum of mice. Compared with group $A$, the content of LD in ICR mice after race walking training is increased. That is, 
after race walking training, the mice are also not treated with traditional Chinese medicine compound preparation by gavage. A large amount of lactic acid is produced in the serum of group $B$, showing the state of race walking fatigue, and the content of $L D$ in serum of group $C$ is decreased, The results showed that the Chinese medicine compound prescription also had certain effect on the mice treated by sitting still. Figure 1 (c) shows the detection results of $L D H$ content in ICR mice. Compared with group A, LDH activity in serum of group B was increased, LDH in group C was significantly decreased, and LDH activity in group $D$ was significantly decreased, and the above results were not statistically different. Figure 1 (d) shows the content of $C K$ in serum of ICR mice. Comparing group A with group $B$, the serum $C K$ content of ICR mice in group $B$ shows a significant increase trend, while the $C K$ content of group $C$ is significantly decreased. Compared with group $A$, the $C K$ content of group $D$ also decreases a lot, and the $P$ values in all results are less than 0.05 . Due to space limitation, the PI content in serum of mice is no longer analyzed here. However, combined with the overall situation shown in Fig. 4 , it can be seen that the traditional Chinese medicine compound has a positive effect on relieving fatigue in mice. The results of the effect of Chinese herbal compound on gastrocnemius muscle of ICR mice are shown in Figure 2.
According to Figure 2, it can be clearly seen that the skeletal muscles of mice in group $A$ and group $C$ have relatively clear transverse lines, and the fibers in skeletal muscles present a state of uniform arrangement. After six days of high-intensity race walking training every week, the mice in group B showed strong race walking fatigue, and their skeletal muscles showed varying degrees of injury, the transverse striation was disordered, the fiber arrangement in gastrocnemius muscle was no longer uniform, and even the phenomenon of gastrocnemius muscle nucleus migration occurred. After the race walking training, the mice in group $D$ also went through the gavage treatment of traditional Chinese medicine compound preparation, so the gastrocnemius muscle fibers were still in the state of uniform arrangement, and the transverse striation was kept in order, and the situation of gastrocnemius muscle nuclear translocation was also significantly improved. The results of immunohistochemical staining showed that there were different expression levels of B-cell lymphoma-2 (Bcl-2) and NF-E2-related actor 2 (Nrf2) in skeletal muscle tissue of ICR mice, as shown in Figure 3.

According to figure 3, Nrf2 was obviously expressed in skeletal muscle tissues of the four groups of mice participating in the experiment, and significant nuclear staining could be observed in ICR mice of group A

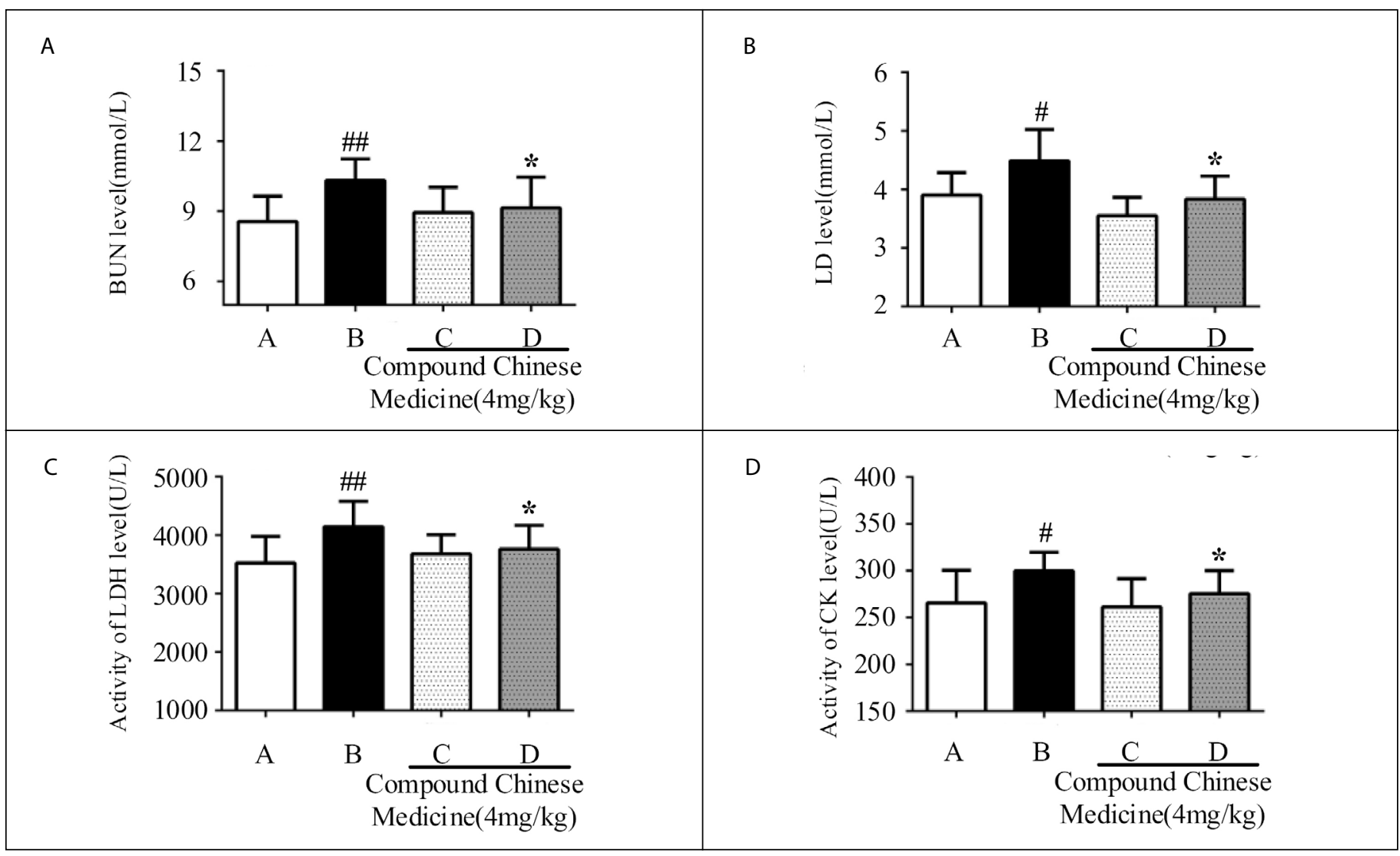

Figure 1. Effect of traditional Chinese medicine compound on fatigue related biochemical indexes in mice.

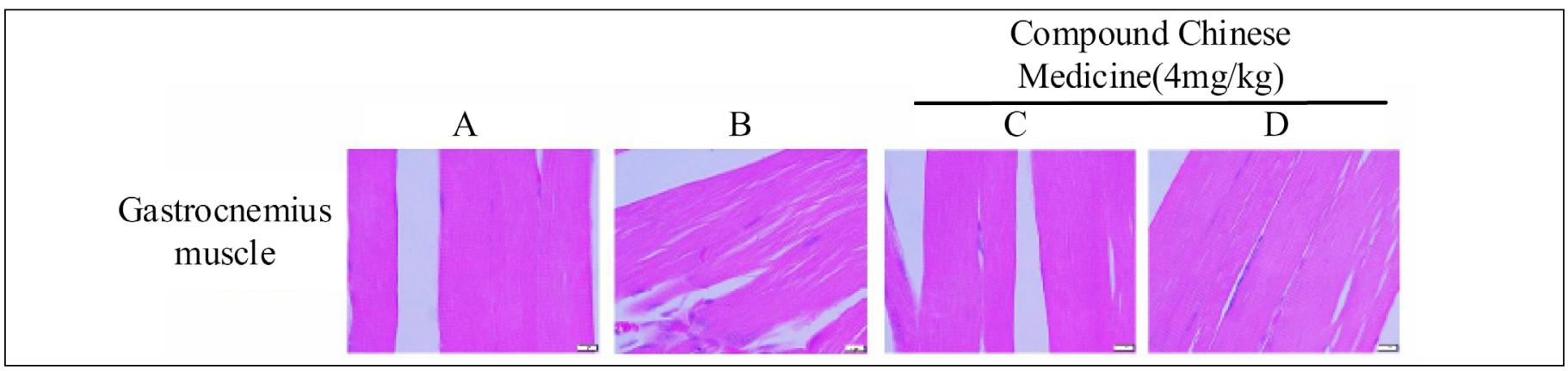

Figure 2. Effect of traditional Chinese medicine compound prescription on histopathology of gastrocnemius muscle in mice. 


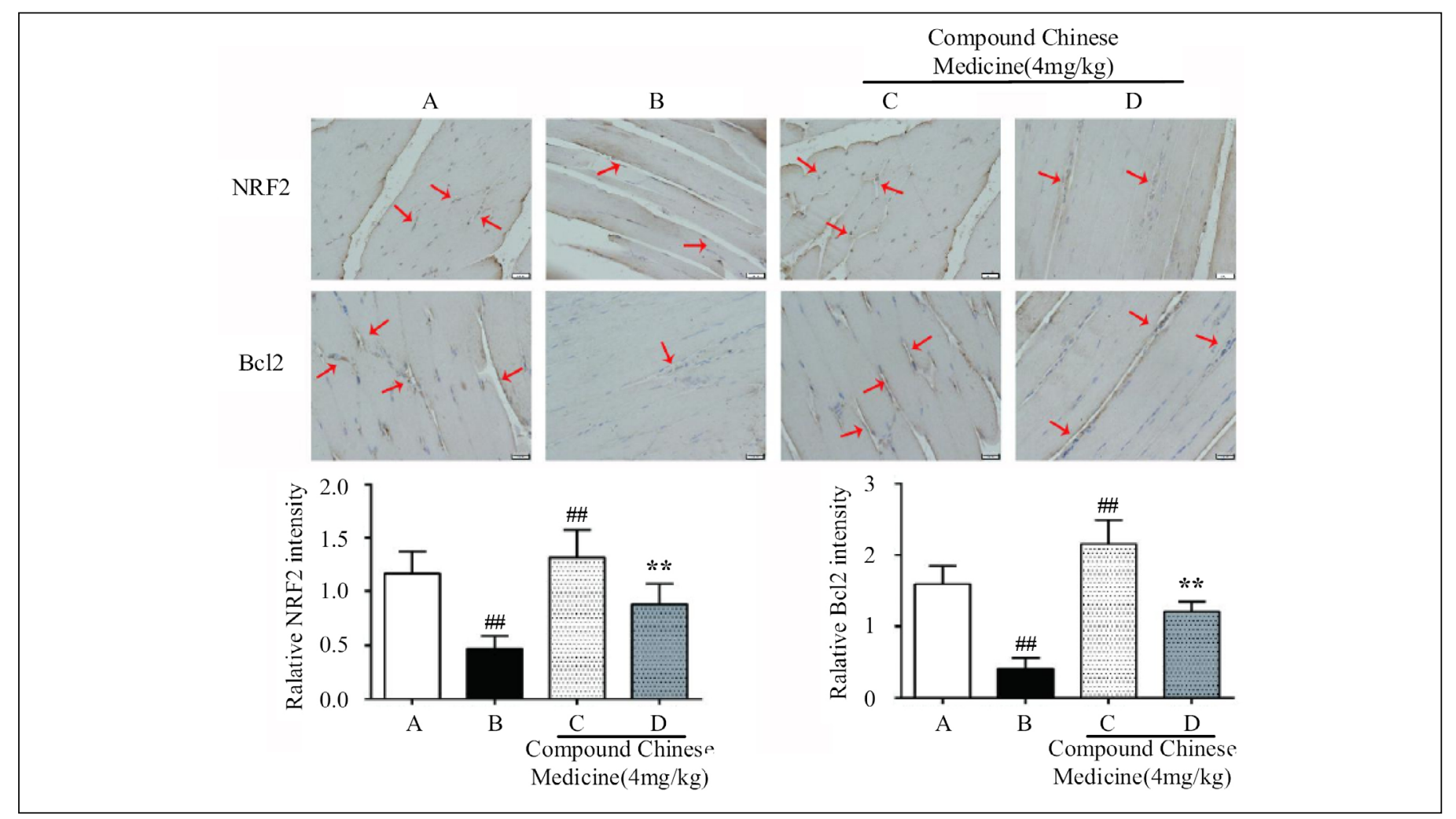

Figure 3. Effect of Chinese herbal compound on the expression of $\mathrm{Nrf} 2$ and $\mathrm{BCl}-2$ in skeletal muscle of mice.

and group C, which indicated that the protein expression level of mice in groups $A$ and $C$ was superior, which was significantly higher than that in group $B$, which was due to the fact that mice in group $B$ had undergone high-intensity walking training without treatment of traditional Chinese medicine. Compared with group C ICR mice, the positive staining of group D ICR mice was more significant, and the positive expression of Nrf2 was increased. Figure 6 shows that most of $\mathrm{BCl}-2$ protein is located at the edge of mouse cell membrane. The protein expression and expression level of ICR mice in groups $A$ and $C$ are higher than those in groups $B$ and $D$, while the positive expression effect of group $D$ is significantly better than that of group B. It shows that race walking training can make ICR mice exercise fatigue and reduce its protein expression level. Chinese herbal compound can effectively alleviate the exercise fatigue of mice and restore its positive expression Expressiveness.

\section{CONCLUSION}

As an indispensable medical means in the world medical field, Chinese medicine has significant curative effect on the treatment of various diseases, and the application range of traditional Chinese medicine compound is more and more extensive. Race walking fatigue is a very common disease, usually seen after a long period of high-intensity race walking exercise, causing great damage to the body of athletes. In order to effectively alleviate the symptoms of race walking fatigue and improve the antioxidant capacity of the body, this study focused on the mechanism and efficacy of traditional Chinese medicine compound, analyzed the causes of fatigue caused by race walking, and carried out ICR mice control experiment. The results showed that the contents of lactic acid and other substances produced in the serum of mice in the blank control group were less than those in the control group, while the experimental group mice in the race walking training group showed obvious race walking fatigue. After intragastric administration of traditional Chinese medicine compound to mice, it can significantly reduce the content of lactic acid and other substances in serum, improve the activity of other biochemical indexes, keep the muscle fibers evenly arranged, and improve the protein expression level, so as to effectively relieve the fatigue symptoms of race walking. Although some achievements have been made in this study, which can provide reference for relieving race walking fatigue, there are still some problems that need to be improved. For example, the curative effect analysis of traditional Chinese medicine compound is not applied to human body, and it is expected to have a more in-depth discussion in the future.

\section{ACKNOWLEDGEMENTS}

The study was supported by "Sports philosophy and social science research project of General Administration of sport of China, China (Grant No.2292SS16029)".

The author declare no potential conflict of interest related to this article

AUTHORS' CONTRIBUTIONS: The author has completed the writing of the article or the critical review of its knowledge content. This paper can be used as the final draft of the manuscript. Every author has made an important contribution to this manuscript. Tao Ma: writing and execution.

\section{REFERENCES}

1. Jung MC, Mo SM. The evaluation of lower-limb muscular fatigue during walking on industrial grating type[J]. Journal of the Korean Institute of Industrial Engineers. 2017;43(4):248-54.

2. Luo Y, Wang CZ, Sawadogo R, Tan T, Yuan CS. Effects of herbal medicines on pain management. Am J Chin Med. 2020;48(1):1-16.

3. Wang YM, Du L, Zhu YJ. Evidence-based therapies of Chinese medicine for chronic urticaria: Where do we stand and where are we going? Chin J Integr Med. 2017;23(8):566-9.

4. Kyle B, Jacob C. Out of gas: quantifying fatigue in MLB relievers. Journal of Quantitative Analysis in Sports. 2018;14(2):57-64.

5. Wu QH, Li BT, Tu J.Compound traditional Chinese medicine in treatment of diabetes. China Journal of Chinese Materia Medica. 2019;44(6):1104-9. 